African Crop Science Journal by African Crop Science Society is licensed under a Creative Commons Attribution 3.0 Uganda License. Based on a work at www.ajol.info/ and www.bioline.org.br/cs DOI: https://dx.doi.org/10.4314/acsj.v28i3.6

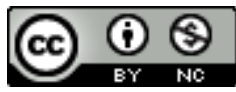

\title{
IMPLICATIONS OF FARMER PERCEIVED PRODUCTION CONSTRAINTS AND VARIETAL PREFERENCES TO PEARL MILLET BREEDING IN SENEGAL
}

\author{
G. KANFANY, O. DIACK ${ }^{1}$, N.A. KANE ${ }^{1}$, P. I. GANGASHETTY ${ }^{2}$, O. SY, A. FOFANA \\ and N. CISSE ${ }^{1}$ \\ Centre National de Recherches Agronomiques de Bambey, Institut Sénégalais de Recherches \\ Agricoles (ISRA/CNRA), BP 211 Bambey, Sénégal \\ ${ }^{1}$ Centre d'Etudes Régional pour l'Amélioration de l'Adaptation à la Sècheresse (CERAAS), Institut \\ Sénégalais de Recherches Agricoles, BP 3320, Route de Khombole, Thies, Sénégal \\ ${ }^{2}$ International Crops Research Institute for the Semi-Arid Tropics (ICRISAT), Niamey, BP 12404, \\ Niger (Via Paris) \\ Corresponding author: kanfanyghislain@yahoo.fr
}

(Received 25 March 2020; accepted 27 August 2020)

\begin{abstract}
Pearl millet (Pennisetum glaucum L.) plays a critical role in smallholder food security in sub-Saharan Africa. The production of pearl millet has, however, stagnated or even declined due to several factors. The objective of this study was to assess farmer perceptions on production constraints and varietal preferences in Senegal. A survey was conducted involving 150 randomly selected farmers from 15 villages, in five representative rural communities of Senegal. A semi-structured questionnaire was used, supplemented by focus group discussions. Results revealed that parasitic Striga weed was the most constraining factor to pearl millet production across the rural communes. This was followed by low soil fertility and insect pests in that order. Other constraints included lack of machinery for sowing, plant diseases, drought, seed-eating birds, limited access to land for pearl millet cultivation and limited seed availability. Among the traits for varietal preference, farmers unanimously considered grain yield as the most important trait. Other important traits mentioned were adaptation to drought, adaptation to low soil fertility and earliness. These production constraints and varietal preference should be integrated in the profile of the national pearl millet breeding programmes in order to improve the productivity and adoption of bred-cultivars.
\end{abstract}

Key Words: Fertility, low soil fertility, Pennisetum glaucum, Striga

\section{RESUME}

Le mil est une importante culture céréalière et joue un rôle essentiel dans la sécurité alimentaire de la plupart des producteurs de l'Afrique subsaharienne. Cependant, la production est oscillante et faible en raison de plusieurs facteurs. Une étude a été conduite pour évaluer la perception des producteurs sur les contraintes limitant la production du mil et leurs préférences variétales au Sénégal. Une enquête 
avec150 producteurs sélectionnés aléatoirement a été menée dans 15 villages situés dans cinq communautés rurales du Sénégal. Une évaluation rurale participative et des enquêtes ont été menées. Les résultats ont montré que le Striga est le facteur majeur qui limite la production de mil au niveau des différentes communautés rurales. Les autres contraintes rencontrées dans les communes rurales étaient le manque de machines pour le semis, les maladies, la sécheresse, les oiseaux granivores, l'accès limité à la terre et la faible disponibilité des semences de variétés améliorées. Les producteurs ont unanimement considéré le rendement en grains comme le trait le plus important dans le choix d'une nouvelle variété. Les autres traits jugés important sont l'adaptation à la sécheresse l'adaptation à la faible fertilité des sols et la précocité. Ces contraintes de production et préférences variétales doivent être incluses parmi les objectifs du programme national de sélection de mil pour améliorer la productivité et le taux l'adoption des nouvelles variétés.

Mots Clés: Fertilité, faible fertilité des sols, Pennisetum glaucum, Striga

\section{INTRODUCTION}

Pearl millet [Pennisetum glaucum (L.) R. Brown] is among the most important cereal crops grown in the arid and semi-arid regions of the tropics, particularly in sub-Saharan Africa (Sehgal et al., 2012). It is an important staple food grain, and fodder and feed for livestock for many households in countries like Senegal. The crop has been the most cultivated cereal in the country, especially in the central part that is the major area of production. The trend of pearl millet yield in Senegal has not been consistent over the past 20 years, oscillating between 464 and $768 \mathrm{~kg} \mathrm{ha}^{-1}$ (FAOSTAT, 2015).

Pearl millet improved cultivars are not widely adopted by Senegalese farmers perhaps due to inadequate levels of awareness; noninclusion of farmers during cultivar development; as well as farmers' inability to afford fertiliser and other inputs, and certain traditional values (Omanya et al., 2007). Failure to involve farmers during pearl millet breeding mostly leads to cultivars that are unattractive to them. Plant breeders, to improve the level of adoption of newly bred pearl millet cultivars, should work closely with farmers through participatory plant breeding, whereby farmers are mobilised and their technical knowledge is integrated during the cultivar development (Bidinger, 1998). This technique is widely embraced by plant breeders to ensure adoption of newly bredcultivars by farmers, particularly in marginal agro-ecological zones (Ceccarelli et al., 2007). In fact, this approach has been demonstrated to enhance adoption of newly bred-cultivars and may help plant breeders to identify farmers' production constraints and preferred traits (Mulatu and Belete, 2001).

There is scanty formal documentation on the main pearl millet constraints and farmers' preferred traits in Senegal. Participatory plant breeding approaches in pearl millet have been, however, conducted in some pearl millet growing areas elsewhere in Africa. Omanya et al. (2007), in their study on the participatory varietal selection using improved pearl millet cultivars in some West Africa countries, indicated that farmers preferred pearl millet cultivars with acceptable grain yield and taste. Recently, a participatory rural appraisal (PRA) conducted in Niger revealed that the main preferred traits for pearl millet cultivars are host plant resistance to pests and diseases; and adaptation to various abiotic stresses especially drought, high grain yield, early maturity and food quality (Issaka, 2012). Previously, farmers that have been involved in pearl millet participatory selection in Namibia were asked to select their preferred cultivars (Monyo et al., 2001). In their study, out of the six cultivars evaluated, most of the farmers selected two owing to their early maturity, drought adaptation, grain size and threshing ability. 
More recently, this participatory approach was undertaken across Africa in other crops such as cassava, finger millet, maize, rice, and sweet potato (Abakemal et al., 2013; Asante et al., 2013; Njoku et al., 2014; Owere et al., 2014; Placide et al. 2015).

Constraints and farmers' preferred traits for a specific crop are also location specific; hence, plant breeders should develop cultivars adapted to a specific location rather than aiming at a wide range of environments (Omanya et al., 2007). Knowledge of production constraints and farmers' preferred traits for a specific location are, therefore, essential to guide any pearl millet breeding programmes to set well targeted objectives. This approach will help the breeding programme to meet farmers' specific needs. The objective of this research was to assess farmers' perception on production constraints and varietal preferences in Senegal so as to be able to improve adoption rate of newly developed cultivars by farmers.

\section{MATERIALS AND METHODS}

Study area. The study was conducted during February and March 2015 in the Groundnut Basin Agro-Ecological zone, located in central Senegal, where groundnut and pearl millet are the predominant crops (FAOSTAT, 2015). Five representative pearl millet growing regions of Senegal, namely Fatick, Kaolack, Diourbel, Thies and Kaffrine were purposively selected based on the importance of pearl millet in terms of production and grown area (Table 1). During 2014 cropping season, these five regions accounted for $74 \%$ of the national harvested pearl millet area, and over $76 \%$ of total pearl millet production (FAOSTAT, 2015).

In each region, one rural commune was selected; i.e., a total of five rural communes were included in this study. Within each rural commune, three villages were selected, providing a total of 15 study sites. Among the selected sites, most of farming activities followed the rainy season, which is uni-modal from June to October, with annual rainfall between 500 to $900 \mathrm{~mm}$. Soils vary, but are mostly sandy with low fertility (Malou et al., 2020).

Sampling method. A multi-sampling procedure was used to select the representative study units. In each region, one rural commune was sampled with the assistance of regional extension officers. The selection was based on the relative importance of pearl millet production in the rural commune. The following rural communes were selected: Malicounda, Ngogom, Kahi, Paoskoto and PatarLia. In each rural commune, three villages were sub-sampled with the help of the local extension officers (Table 1). Within each village, 10 farmers were randomly selected providing a total of 150 pearl millet farmers for the semi-structured interviews. In addition, focus group discussions were held in each of

TABLE 1. Characteristics of selected pearl millet production areas in Senegal

\begin{tabular}{lcccccc}
\hline Regions & $\begin{array}{c}\text { Altitude } \\
(\mathrm{m})\end{array}$ & $\begin{array}{c}\text { Pearl millet } \\
\text { production } \\
\text { (metric tonnes) }\end{array}$ & $\begin{array}{c}\text { Pearl millet } \\
\text { cultivated } \\
\text { area (ha) }\end{array}$ & Soil type & $\begin{array}{c}\text { Average } \\
\text { precipitation } \\
(\mathrm{mm})\end{array}$ & $\begin{array}{l}\text { Selected } \\
\text { community }\end{array}$ \\
\hline Thies & 71 & 31747 & 81482 & Sandy & 526 & Malicounda \\
Diourbel & 7 & 46231 & 105277 & Sandy & 549 & Ngogom \\
Fatick & 6 & 80000 & 130000 & Sandy & 638 & Patar Lia \\
Kaolack & 6 & 77613 & 132508 & Sandy-clay & 655 & Paoskoto \\
Kaffrine & 11 & 68768 & 89157 & Sandy-clay & 655 & Kahi \\
\hline
\end{tabular}


the three selected villages that constitute one rural commune; hence three focus group discussion per each of the five rural communes.

Data collection. Data were collected using PRA approaches, through focus group discussion (FGD) and followed by semistructured interviews. In each of the FGDs, five pearl millet farmers were involved, making a total of 15 farmers per rural commune. The discussions were held in order to determine the farmers' agronomic practices, major crops and pearl millet cultivars grown, preferences for new pearl millet cultivars and main constraints limiting production.

After the group discussions, 10 farmers per village with their prior informed consent were interviewed individually using semistructured questionnaires. The questionnaire had three components: demographic information, pearl millet production constraints and farmers' trait preferences of pearl millet varieties. Hence, 150 farmers from the five rural communes were involved in the survey. This allowed farmers the exclusivity to express their own views without any community influence. Each farmer interview session lasted at most 30 minutes, and was held within the environments of the household.

Data analysis. Data collected during the survey were coded and entered using Microsoft Excel. The analysis was done using the Statistical Package for Social Sciences (SPSS) version 17. Variables were subjected to descriptive statistics, cross tabulation, onesample $\mathrm{t}$ (two-sided) and Fischer tests.

\section{RESULTS}

Demographic characteristics. The characteristics of sampled farmers for the formal household survey are presented in Table 2 . The number of males involved in the study was higher than the females. Of the total farmers interviewed, $93.3 \%$ were males; while only $6.7 \%$ were females. Among the respondents, $73.3 \%$ never attended school, $18 \%$ had finished primary school, $8 \%$ were educated up to post-primary level and less than $1 \%$ had attended secondary school. About $51 \%$ of the farmers belonged to farmers' associations.

Production constraints. The major constraints to pearl millet production were identified and listed during the FGDs (Table 3 ). These constraints were ranked by each interviewed individual farmer. The Striga parasitic weed, low soil fertility and insect pests were the three most important constraints reported by pearl millet farmers; yet unavailability of seeds was viewed as the least important constraint. Other important constraints across the five rural communes were lack of machinery for sowing, plant diseases, drought, limited access to arable land and seed-eating birds.

There were locational differences of perceptions and varietal differences between rural communes. Farmers in Patar Lia ranked low soil fertility as the priority constraint, followed by Striga, lack of machinery, insect pests, diseases, seed availability, drought and seed-eating birds. However, farmers in Paoskoto, Kahi and Ngogom ranked Striga, followed by low soil fertility, insect pests and lack of machinery for sowing as the major constraints, in that order. In Malicounda, the major constraints were insect pests, Striga and seed-eating birds.

Farmers' preferences traits. During the FGDs, farmers mentioned different criteria used to select pearl millet cultivars (Table 4). A significant difference was observed in ranking pearl millet trait preferences by farmers between rural communes, except for grain colour and resistance to biotic stress traits. High grain yield was by far the most important trait for this purpose. Other important traits mentioned were adaptation to abiotic stresses such as drought and low soil fertility, early 
TABLE 2. Characteristics of pearl millet farmers interviewed in Senegal

\begin{tabular}{|c|c|c|c|c|c|c|c|c|}
\hline \multirow[t]{2}{*}{ Variable } & \multicolumn{5}{|c|}{ Rural communities } & \multirow[t]{2}{*}{ Total } & \multirow[t]{2}{*}{ Percentage } & \multirow[t]{2}{*}{$\mathrm{P}$ value } \\
\hline & Paoskoto & Kahi & Ngogom & Malicounda & Patar Lia & & & \\
\hline \multicolumn{9}{|l|}{ Gender } \\
\hline Male & 29 & 27 & 25 & 29 & 30 & 140 & 93.3 & 0.075 \\
\hline Female & 1 & 3 & 5 & 1 & 0 & 10 & 6.7 & \\
\hline \multicolumn{9}{|c|}{ Belongs to an association } \\
\hline Yes & 11 & 15 & 10 & 24 & 17 & 77 & 51.3 & 0.002 \\
\hline No & 19 & 15 & 20 & 6 & 13 & 73 & 48.3 & \\
\hline \multicolumn{9}{|c|}{ Level of education } \\
\hline No education & 22 & 26 & 25 & 17 & 21 & 111 & 73.3 & 0.18 \\
\hline Primary & 6 & 2 & 3 & 8 & 8 & 27 & 18 & \\
\hline Post primary & 2 & 1 & 2 & 5 & 2 & 12 & 8 & \\
\hline Secondary & 0 & 1 & 0 & 0 & 0 & 1 & 0.7 & \\
\hline
\end{tabular}


TABLE 3. Mean ranking of pearl millet constraints across the locations in Senegal

\begin{tabular}{|c|c|c|c|c|c|c|c|c|}
\hline \multirow[t]{2}{*}{ Constraints* } & \multicolumn{5}{|c|}{ Rural communities } & \multirow[t]{2}{*}{ Mean } & \multirow[t]{2}{*}{ Rank } & \multirow[t]{2}{*}{$P$ value } \\
\hline & Paoskoto & Kahi & Ngogom & Malicounda & Patar & & & \\
\hline Striga & 2.2 & 2.4 & 2.7 & 2.3 & 2.8 & 2.5 & 1 & 0.269 \\
\hline Low soil fertility & 2.6 & 2.6 & 3.1 & 5.2 & 1.6 & 3 & 2 & $<0.001$ \\
\hline Downy mildew & 6.6 & 5.8 & 6.2 & 6.2 & 5.5 & 6 & 6 & 0.162 \\
\hline Drought & 5.4 & 6.7 & 5.5 & 4.7 & 6.5 & 5.7 & 5 & 0.004 \\
\hline Insects & 3.9 & 3.8 & 4.5 & 2.2 & 3.9 & 3.6 & 3 & $<0.001$ \\
\hline Lack machinery for sowing & 5.1 & 3.6 & 4.6 & 6.5 & 3.7 & 4.7 & 4 & $<0.001$ \\
\hline Land tenure & 6.2 & 6.7 & 4.7 & 6.9 & 6.3 & 6.1 & 7 & 0.01 \\
\hline Limited seeds availability & 6.3 & 7.2 & 7 & 8.1 & 5.9 & 6.9 & 9 & 0.014 \\
\hline Seed-eating birds & 7.2 & 6.9 & 6.4 & 4.6 & 7.2 & 6.5 & 8 & $<0.001$ \\
\hline
\end{tabular}

*Constraint with smallest mean rank within a column is perceived to be the most important

TABLE 4. Mean ranking of the most important preferred traits across the locations

\begin{tabular}{|c|c|c|c|c|c|c|c|c|}
\hline \multirow[t]{2}{*}{ Characteristics* } & \multicolumn{5}{|c|}{ Rural communities } & \multirow[t]{2}{*}{ Mean } & \multirow[t]{2}{*}{ Rank } & \multirow[t]{2}{*}{$\mathrm{P}$ value } \\
\hline & Paoskoto & Kahi & Ngogom & Malicounda & Patar & & & \\
\hline High grain yield & 1.2 & 1.6 & 1.4 & 1.2 & 1.2 & 1.3 & 1 & 0.058 \\
\hline Grain colour & 3.7 & 4.2 & 3.7 & 4.3 & 3.8 & 3.9 & 5 & 0.136 \\
\hline biotic stress & 3.3 & 2.7 & 3.4 & 3.3 & 3.3 & 3.2 & 2 & 0.072 \\
\hline abiotic stress & 2.9 & 2.8 & 3.5 & 3.8 & 3.1 & 3.6 & 4 & 0.01 \\
\hline Early maturity & 3.9 & 3.5 & 3.1 & 2.3 & 3.2 & 3.3 & 3 & $<0.001$ \\
\hline
\end{tabular}

*Characteristic with smallest mean rank within a rural commune is perceived to be the most important 
maturity, grain colour, and host plant resistance to insects, pathogens and Striga. In Ngogom and Malicounda, earliness was identified as the second most important trait; whereas in Paoskoto, Patar Lia and Kahi host plant resistance to Striga and adaptation to low soil fertility were ranked after high grain yield. In general, farmers from the five different rural communes did not consider grain colour as an important trait.

\section{DISCUSSION}

The gender imbalance observed in this study is historical due to socio-cultural considerations which are typical of the rainfall production system in most of the West and Central African countries (Guirkinger and Platteau, 2014). The results reveal that men dominated predominantly pearl millet in the study areas, possibly because the pearl millet farming activities are traditionally done by men. Furthermore, compared to men, women do not have equal chances to access arable lands, a pre-requisite for pearl millet production, due to some socio-economic considerations (West, 2010). It is culturally known that pearl millet cultivation in WCA is done by men who possess the lands (Theriault et al., 2017). As the head of the family, men are responsible for managing collectively farmed plots and this was confirmed by the present study. The very few women who are allocated lands $(6.7 \%)$ chose to cultivate cash crops such as groundnuts or vegetables to finance family needs. Dominance of men in production of cereal crops has also been reported in other regions in Africa (Sow et al., 2015).

Damages due to Striga and low soil fertility are considered as the key constraints limiting pearl millet production, prompting the need to prioritise these two constraints in any pearl millet improvement programme targeted this region. This finding confirms the deteriorating state of soil fertility and persistence of Striga infestation in major pearl millet production areas in West Africa, especially in Senegal
(Samaké et al., 2006). The most probable causes of this observation are overexploitation of farmland, resulting from demographic pressure, coupled with limited soil conservation practices. In fact, farmers lack the cash to buy the sufficient fertilisers needed, even though they were aware that nutrient deficiency could increase Striga infestation. This farmers' perception agrees with earlier research in maize conducted by Jamil et al. (2012), who pointed out that Striga seed germination percentage increased under $\mathrm{N}$ and $\mathrm{P}$ deficiency.

The traditional measures taken by farmers to tackle Striga infestation in the study area was crop rotation with groundnut and in some extend the use of fertiliser to contribute to soil fertility. During these past years, some attempts have been made by the International Crop Research Institute for the Semi-Arid Tropics (ICRISAT) at Sadore in Niger, to develop resistant cultivars to Striga (Kountche et al., 2013). Hence, pearl millet Striga resistant experimental cultivars were bred and can now be tested in Striga infested farmers' fields (Kountche et al., 2013). These experimental cultivars may contribute to integrated Striga control in pearl millet growing areas in subSaharan Africa.

Insect infestation is another constraint that farmers dealt with in the groundnut agroecological zone in Senegal. There were highly significant differences across sites for the constraint due to insect pests. In Malicounda, it was perceived as being the main constraint compared to the others study sites where Striga and low soil fertility are the main constraints.

It was noted from the study that high grain yield was the most important trait in adopting pearl millet cultivars. Participatory research conducted in some pearl millet growing areas in West African countries and Namibia also found that high grain yield was an important criterion in selected pearl millet cultivars by farmers (Monyo et al., 2001; Omanya et al., 2007; Issaka, 2012). The prioritisation of high 
grain yield as the key criterion indicated for varietal selection clearly underscores the important role that pearl millet plays as a food crop in this part of the country. Unfortunately, most of the farmers still depend on seeds from local landraces, carefully selected from previous seasons. Moreover, all the improved pearl millet cultivars grown by some farmers in Senegal were open pollinated; hence, the introduction and breeding of hybrid pearl millet cultivars, which have theoretically higher grain yield than open pollinated cultivars, could be an effective way to increase grain yield and consequently meet farmers' needs. In India, where more than $70 \%$ of pearl millet area is sown with single-cross hybrids, grain production considerably increased while areas sown with this crop have declined (Hash et al., 2006). In West African countries, hybrid breeding programmes have recently restarted with focus on identification of heterotic groups and development of pearl millet hybrids with superior productivity and grain yield stability (Sattler et al., 2019). Additionally, efforts have been made in developing cytoplasmic male sterility (CMS) lines from Senegalese germplasm (Pucher et al., 2016). However, there is need to strengthen the private hybrid seed sector and increase marketing opportunities.

Apart from preference for high-yielding cultivars, all other preferences traits were unevenly ranked for any given rural commune, showing that they depended greatly on specific localities. For instance, short growth cycle was identified in Ngogom and Malicounda as the second most important trait probably because of the rainfall pattern with shorter rainy periods compared to the other rural communes. Hence, breeding efforts for this part of the country should focus on developing high-yielding and early-maturing cultivars that will considerably minimise crop loss through drought escape. In order to increase adoption of newly bred pearl millet cultivars and meet farmers' needs in the groundnut basin of Senegal, pearl millet breeders should take in consideration these varietal preferences. The findings of the preferred traits from this study will considerably have implications and reorient pearl millet breeding programmes in Senegal, specifically in the groundnut basin agroecological zone where farmers grow mainly pearl millet.

\section{ACKNOWLEDGEMENT}

The authors are thankful to the West Africa Agricultural Productivity Program (WAAPP). This work could not have been done without the funding received from the WAAPP.

\section{REFERENCES}

Abakemal, D., Hussein, S., Derera, J. and Laing, M. 2013. Farmers' perceptions of maize production systems and breeding priorities, and their implications for the adoption of new varieties in selected areas of the highland agro-ecology of Ethiopia. Journal of Agricultural Science 5(11):159171.

Asante, M. D., Asante, B. O., Acheampong, G. K., Offei, S. K., Gracen, V., AduDapaah, H. and Danquah, E. Y. 2013. Farmer and consumer preferences for rice in the Ashanti region of Ghana: Implications for rice breeding in West Africa. Journal of Plant Breeding and Crop Science 5(12): 229-238.

Bidinger, F. R. 1998. Farmer participation in pearl millet research in Namibia. Participatory Plant Improvement Conference Proceeding 21-30.

Ceccarelli, S., Grando, S., and Baum, M. 2007. Participatory plant breeding in waterlimited environments. Experimental Agriculture 43(4):411-436.

FAOSTAT. 2015. FAO Database, Statistiques Agricoles, viewed 12 March 2017, <http:/ /faostat.fao.org>

Guirkinger, C. and Platteau, J. P. 2014. The effect of land scarcity on farm structure: 
empirical evidence from Mali. Economic Development and Cultural Change 62(2): 195-238.

Hash, C. T., Sharma, A., Kolesnikova-Allen, M. A., Singh, S. D., Thakur, R. P., Raj, A. B., Rao, M. R., Nijhawan, D. C., Beniwal, C. R., and Sagar, P. 2006. Teamwork delivers biotechnology products to Indian small-holder crop-livestock producers: Pearl millet hybrid "HHB 67 Improved" seed delivery pipeline. Journal of SAT Agricultural Research 2(1):1-3.

Issaka, A. 2012. Development of Downy Mildew Resistant F1 pearl millet Hybrids in Niger. PhD. Thesis. University of Ghana, Ghana. 132pp.

Jamil, M., Kanampiu, F. K., Karaya, H., Charnikhova, T. and Bouwmeester, H. J. 2012. Striga hermonthica parasitism in maize in response to $\mathrm{N}$ and $\mathrm{P}$ fertilisers. Field Crops Research 134: 1-10.

Kountche, B. A., Hash, C. T., Dodo, H., Laoualy, O., Sanogo, M. D., Timbeli, A., Vigouroux, Y., This, D., Nijkamp, R. and Haussmann, B. I. G. 2013. Development of a pearl millet Striga-resistant genepool: Response to five cycles of recurrent selection under Striga-infested field conditions in West Africa. Field Crops Research 154: 82-90.

Malou, O. P., Sebag, D., Moulin, P., Chevallier, T., Badiane-Ndour, N. Y., Thiam, A. and Chapuis-Lardy, L. 2020. The Rock-Eval® signature of soil organic carbon in arenosols of the Senegalese groundnut basin. How do agricultural practices matter? Agriculture, Ecosystems and Environment 301(2020):1-12

Monyo, E. S., Ipinge, S. A., Geoffrey, M. H. and Chinhema, E. 2001. Participatory breeding: does it make a difference? Lessons from Namibian pearl millet farmers. Proceedings of Assessing the Impact of Using Participatory Research and Gender Stakeholder Analysis, Quito Ecuador. N. Lilja, J. A. Ashby and L. Sperling (Eds.). Participatory Research and
Gender Analysis Program, CGIAR. pp. 198-207

Mulatu, E. and Belete, K. 2001. Participatory varietal selection in lowland sorghum in eastern Ethiopia: Impact on adoption and genetic diversity. Experimental Agriculture 37(2): 211-229.

Njoku, D. N., Egesi, C. N., Gracen, V. E., Offei, S. K., Asante, I. K. and Danquah, E. Y. 2014. Identification of Pro-vitamin A Cassava ( Manihot esculenta Crantz ) Varieties for. Journal of Crop Improvement 28(3): 361-376.

Omanya, G. O., Weltzien-Rattunde, E., Sogodogo, D., Sanogo, M., Hanssens, N., Guero, Y. and Zangre, R. 2007. Participatory varietal selection with improved pearl millet in West Africa. Experimental Agriculture 43(1): 5-19.

Owere, L., Tongoona, P., Derera, J. and Wanyera, N. 2014. Farmers' perceptions of inger millet production constraints, varietal preferences and their implications to finger millet breeding in Uganda. Journal of Agricultural Science 6(12):126-138.

Placide, R., Shimelis, H., Laing, M. and Gahakwa, D. 2015. Farmers' perceptions, production and productivity constraints, preferences, and breeding priorities of sweetpotato in Rwanda. HortScience 50(1): 36-43.

Pucher, A., Sy, O., Sanogo, M.D., Angarawai, I.I., Zangre, R., Ouedraogo, M., Boureima, S., Hash, C.T. and Haussmann, B.I., 2016. Combining ability patterns among West African pearl millet landraces and prospects for pearl millet hybrid breeding. Field Crops Research 195:.9-20.

Samake, O., Stomph, T. J., Kropff, M. J., \& Smaling, E. M. A. 2006. Integrated pearl millet management in the Sahel: Effects of legume rotation and fallow management on productivity and Striga hermonthica infestation. Plant and soil 286: 245-257.

Sattler, F. T., Pucher, A., Kassari Ango, I., Sy, O., Ahmadou, I., Hash, C. T. and 
Haussmann, B. I. 2019. Identification of combining ability patterns for pearl millet hybrid breeding in West Africa. Crop Science 59(4): 1590-1603.

Sehgal, D. V., Armstead, I. P., Vadez, V., Yadav, Y. P., Hash, C. T. and Yadav, R. S. 2012. Integration of gene-based markers in a pearl millet genetic map for identification of candidate genes underlying drought tolerance quantitative trait loci. BMC Plant Biology 12(1): 9.

Sow, M., Seck, P. A., Maiga, I. M., Laing, M., Ortiz, R. and Ndjiondjop, M.-N. 2015. Farmers' rice knowledge and adoption of new cultivars in the Tillabéry region of western Niger. Agriculture \& Food Security 4(1): 12.

Theriault, V., Smale, M. and Haider, H. 2017. How does gender affect sustainable intensification of cereal production in the West African Sahel? Evidence from Burkina Faso. World Development 92: 177-191.

West, C. T. 2010. Household extension and fragmentation: Investigating the socioenvironmental dynamics of Mossi domestic transitions. Human Ecology 38(3): 363376. 